\title{
TIPOLOGI PINTU DAN JENDELA PADA FASAD RUMAH DI KAMPUNG BIRU AREMA KELURAHAN KIDULDALEM
}

\author{
Muhammad Andi Finaldi Nurtantyo ${ }^{1}$, Respati Wikantiyoso ${ }^{2}$ \\ afinaldi@ymail.com¹/085733895660,respati_w@yahoo.com²
}

\begin{abstract}
Abstrack
Keywords:

Facades, typology, doors, windows

One mindset about the development of thematic villages around the riverbank area (DAS) is about the new paradigm coming from the Malang city government. Jodipan (KWJ) Colorful kampong, 3D kampong (tridi), and White kampong in Klojen kampong can now be said to have been transformed because of this mindset. Currently there were new tourist villages, namely Kampung Biru Arema, which located in the Kiduldalem sub-district, which that had just been formalized and was in the process of being changed different with Jodipan, which has a variety of distinguished building color characteristics, Kampung Biru Arema only had one color that matches its name, which is blue. One of the characteristics that can distinguish between buildings with another to understand is the characteristics of the facade type a building. It can see these elements in the form of door and window opening elements. The purpose of this study was to identify the typology of doors and windows on the facades of houses in Kampung Biru Arema. The method used in this paper is descriptive qualitative method, with a typology approach. The residential building is chosen as an object through the purposive sampling method. This study focused on the identification and analysis of door and window elements in house facades located in Kampung Biru Arema RW.05 neighborhood of Kiduldalem village, Malang city.
\end{abstract}

Kata kunci:

Fasad, tipologi, pintu, jendela

\section{Abstrak}

Salah satu pola pikir mengenai pembangunan kampung tematik yang ada di sekitar wilayah bantaran sungai (DAS) adalah tentang paradigma baru berasal dari pemerintah kota Malang. Kampung Warna-warni Jodipan (KWJ), Kampung 3D (tridi), maupun Kampung Putih di Kelurahan Klojen saat ini dapat dikatakan telah bertransformasi sebagai hasil dari pola pikir tersebut. Saat ini terdapat kampung wisata baru yaitu Kampung Biru Arema yang berada di kelurahan Kiduldalem baru diresmikan dan sedang dalam proses perwajahan. Berbeda dengan Jodipan yang memiliki beragam karakteristik warna bangunan yang dapat dibedakan, Kampung Biru Arema hanya memiliki satu warna yang sesuai dengab namanya, yaitu warna biru. Salah satu karakteristik yang dapat membedakan antara bangunan satu dengan yang lain yaitu dengan memahami karakteristik tipe dari elemen fasad bangunan. Dapat dilihat elemen tersebut berupa elemen bukaan pintu dan jendela. Tujuan dari penelitian ini adalah untuk mengidentifikasi tipologi pintu dan jendela pada fasad rumah di Kampung Biru Arema. Metode yang digunakan dalam tulisan ini metode kualitatif deskriptif, dengan pendekatan tipologi. Bangunan rumah tinggal tersebut dipilih menjadi objek melalui tahap metode purposive sampling. Penelitian ini berfokus pada identifikasi dan analisa elemen pintu dan jendela pada fasad rumah yang berada di permukiman Kampung Biru Arema RW.05 kelurahan Kiduldalem kota Malang. 


\section{Pendahuluan}

Salah satu pola pikir mengenai pembangunan kampung tematik yang ada di sekitar wilayah bantaran sungai (DAS) adalah tentang paradigma baru berasal dari pemerintah kota Malang yang menjadikan pemukiman di zona rawan tersebut sebagai salah satu solusi pembangunan kota Malang. Kampung Warna-warni Jodipan (KWJ), Kampung 3D (tridi), maupun Kampung Putih di Kelurahan Klojen, saat ini dapat dikatakan telah bertransformasi sebagai solusi yang dimaksud. Dengan berbasis ide dan aspirasi masyarakat di lingkungannya, solusi pembangunan baru terus diwujudkan dan digencarkan oleh pemerintah kota Malang. Saat ini terdapat kampung wisata baru yaitu Kampung Biru Arema yang berada di kelurahan Kiduldalem baru diresmikan dan sedang dalam proses perwajahan.

Kampung Biru Arema lokasinya berada di kecamatan Klojen yang berseberang dengan Kampung Warna-warni Jodipan yang dibelah oleh jembatan embong brantas. Berbeda dengan Jodipan yang memiliki beragam karakteristik warna bangunan yang dapat dibedakan, Kampung Biru Arema hanya memiliki satu warna yang sesuai dengab namanya, yaitu warna biru. Kombinasi warna biru tua dan biru muda mendominasi permukiman di Kampung Biru Arema. Salah satu karakteristik yang dapat membedakan antara bangunan satu dengan yang lain yaitu dengan memahami karakteristik tipe dari elemen fasad bangunan. Dapat dilihat elemen tersebut berupa elemen bukaan pintu dan jendela.

Bukaan pintu dan jendela telah berkembang seiring zaman dan di semua daerah, tetapi tujuan utamanya untuk memasukkan sinar matahari kedalam ruangan. Pintu dan jendela merupakan elemen dari fasad bangunan yang dapat mengadaptasi iklim luar ke dalam bangunan (Marwati, 2017).

Fungsi bukaan pintu tidak hanya sebatas akses sirkulasi, tetapi juga sebagai transisi ruang, penghubung antar ruang, dan juga sebagai pengaman. Oleh karena itulah setiap desain pintu harus mempertimbangkan fungsi dan peletakannya. Fungsi pintu sebagai penghubung antar ruang sangat mempengaruhi kualitas visual dari pemilik bangunan. Fungsi bukaan jendela memiliki peranan penting sebagai memberikan kenyamanan dengan sirkulasi udara dan memasukkan cahaya kedalam ruangan. Selain itu juga fungsi jendela sebagai pelengkap visual disamping pintu. Bentukan pintu dan jendela pada rumah di permukiman kampung biru arema memiliki karakteristik yang baik dari segi fungsi, bentuk dan materialnya.

Pada penelitian ini merupakan studi mengenai tipologi morfologi pintu dan jendela pada fasad rumah kolonial sangat perlu dilakukan khususnya di Kampung Biru. Hal tersebut karena bangunan bergaya kolonial belanda memiliki karakter yang khas, yaitu mampu beradaptasi dengan iklim setempat. Oleh karena hal tersebut desain pintu dan jendela perlu diperhatikan karena memiliki peranan yang penting terhadap identitas dan kenyamanan pemilik rumah. Selain itu juga untuk menambah nilai estetika pada kualitas visual bangunan.

Bentuk pintu dan jendela yang terdapat di rumah tinggal Kampung Biru dapat dijadikan identitas wilayah yang mudah dikenal. Bentukan pintu dan jendela pada fasad bangunan rumah tinggal di Kampung Biru memiliki bentuk unik, sehingga hal tersebut dapat dijadikan sebagai objek studi.

\section{Tujuan}

Tujuan dari penelitian ini adalah untuk mengidentifikasi tipologi pintu dan jendela pada fasad rumah di Kampung Biru Arema, kelurahan Kiduldalem, kota Malang. 


\section{Tipologi Pintu dan Jendela pada Fasad Rumah di Kampung Biru Arema Kelurahan Kiduldalem Muhammad Andi Finaldi Nurtantyo ${ }^{1}$, Respati Wikantiyoso ${ }^{2}$}

\section{Manfaat}

1. Bagi peneliti, diharapkan menambah wawasan dan pengetahuan mengenai kajian tipologi khususnya dalam studi kasus elemen pintu dan jendela fasad rumah di Kampung Biru Arema.

2. Bagi kalangan akademik, diharapkan dapat menjadi bahan penelitian selanjutnya yang lebih spesifik.

3. Bagi pemerintah kota dan pemerintah setempat diharapkan menjadi bahan pertimbangan dalam menetapkan suatu kebijakan tentang karakteristik suatu wilayah permukiman khususnya kampung wisata.

\section{Bahan dan Metode Penelitian}

\section{Bahan Peneitian}

\section{Tipologi}

Dalam memecahkan masalah yang dikaji, beberapa teori arsitektur yang digunakan adalah teori tipologi dan tipomorfologi. Terkait dengan tipologi, (Iswati, 2003) menyatakan sebagai berikut:

"Tipologi adalah studi tentang tipe. Tipe adalah kelompok dari objek yang memiliki ciri khas struktur formal yang sama. Tipologi merupakan studi tentang pengelompokan objek sebagai model, melalui kesamaan bentuk dan struktur, yaitu studi tentang tipe dengan kegiatan kategorisasi dan klasifikasi untuk menghasilkan tipe. Kegiatan kategori dan tipe tersebut sekaligus dapat dilihat keragaman dan keseragamannya."

Menurut (Johnson, 1994), tipologi adalah kajian tipe. Tipe berasal dari kata typos (Yunani) yang berarti impresi, gambaran, atau figur dari suatu objek. Secara umum, tipe sering digunakan untuk menjelaskan bentuk keseluruhan, struktur, atau karakter dari suatu bentuk atau objek tertentu. Menurut (Rossi, 1982), jika ditinjau dari objek bangunan, tipologi terbagi atas tiga hal pokok, yaitu site (tapak) bangunan, form (bentuk) bangunan, dan organisasi bagian-bagian bangunan tersebut (Keling, 2016).

Berdasarkan teori yang dikemukakan di atas, dapat disimpulkan bahwa tipologi adalah suatu ilmu yang mempelajari segala sesuatu tentang tipe. Tipologi arsitektur atau dalam hal ini tipologi bangunan erat kaitannya dengan suatu penelusuran elemen-elemen pembentuk suatu sistem objek bangunan atau arsitektural. Elemen-elemen tersebut merupakan organisme arsitektural terkecil yang berkaitan untuk mengidentifikasi tipologi dan untuk membentuk suatu sistem. Elemen-elemen tersebut mengalami suatu proyek komposisi, seperti penggabungan, pengurangan, stilirisasi bentuk, dan sebagainya. Teori tipologi dalam penelitian ini digunakan untuk mengklasifikasikan data melalui kesamaan bentuk, struktur, dan karakter dari bangunan (Keling, 2016).

Tipologi menurut Zahnd (1999) dalam (Mulyandari, TIPOLOGI RUMAH SUSUN YOGYAKARTA, 2012) didefinisikan sebagai klasifikasi watak atau karakteristik dari formasi objek-objek bentukan fisik kota dalam skala lebih kecil. Istilah tipologi lebih banyak digunakan untuk mendefinisikan bentuk elemen-elemen kota seperti jalan, ruang terbuka hijau, bangunan dan lain sebagainya. Gambaran berikut dari Zahnd (1999) tentang tipologi masa bangunan (Blok) (Mulyandari, TIPOLOGI PERUBAHAN FUNGSI LAHAN BANGUNAN DI PERKOTAAN STUDI KASUS PERKEMBANGAN BANGUNAN KOMERSIAL PENGGAL JALAN MONJALI - JALAN ABU BAKAR ALI YOGYAKARTA, 2014). 
LOCAL WISDOM, Vol. 10 No. 2 Juli 2018

Local Wisdom Scientific Online Journal

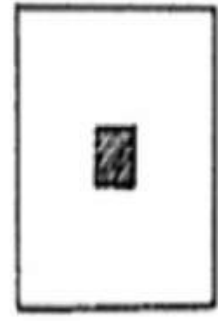

Blok Tunggal

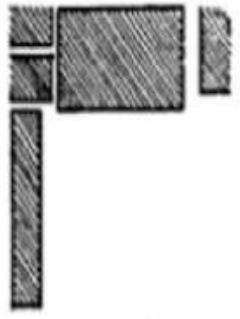

Blok sebagi Tepi

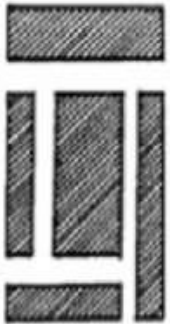

Blok Medan

Gambar 1. Tipologi massa bangunan

Sumber: Zahnd (1999) dalam (Mulyandari, TIPOLOGI RUMAH SUSUN YOGYAKARTA, 2012)

Tipologi digunakan sebagai alat untuk menganalisis obyek. Dengan tipologi suatu obyek arsitektur dapat dianalisis perubahan-perubahan yang berkaitan dengan bangun dasar, sifat dasar, serta proses perkembangan bangunan dasar tersebut. Selain itu tipologi juga dapat digunakan untuk menerangkan perubahan-perubahan dari suatu tipe, karena suatu tipe memiliki ciri-ciri tertentu yang membedakannya dari tipe yang lain. Jadi dengan kata lain tipologi adalah ilmu yang mempelajari klasifikasi dari tipe, yaitu dengan cara mempelajari karakeristik yang lebih spesifik dari suatu bangunan. Dengan demikian, maka tipologi tidak hanya dibedakan dari bentuknya saja tetapi lebih kearah pada karakter bangunan (Mariana, 2013). Karakter bangunan dapat tercemin dalam wujud fasad bangunan. Menurut (Krier, 1988) dalam bukunya yang berjudul Architectural Composition (1988) mengemukakan bahwa elemen yang paling penting dan menjadi main poin untuk mengkomunkasikan karakter dan fungsi bangunan adalah komposisi fasad bangunan. Krier juga mengemukakan juga komposisi fasad bangunan akan tercipta harmonis dan proporsional jika mempertimbangkan semua aspek persyaratan secara fungsional. Oleh karena itu sangatlah penting dalam memperhatikan proporsi elemen bukaan pada fasad bangunan. Krier menyebutkan beberapa elemen terpenting membentuk komposisi fasad pada bangunan yaitu: pintu, jendela, dinding, atap, shading (Krier, 1988).

\section{Metode}

Metode penelitian ini pada dasarnya merupakan cara ilmiah untuk mendapatkan data dengan tujuan dan kegunaan tertentu. Penelitian ini menggunakan metode kualitatif deskriptif untuk menggali informasi lebih mendalam, terstruktur, dan menyeluruh berdasarkan informasi pada setiap informan. Di samping itu, peneliti juga ingin menggali secara mendalam informasi yang ada di objek penelitian.

Untuk membahas kajian ini penulis menggunakan pendekatan tipologi (Hersanti, Pangarsa, \& Antariksa, 2008) yang dilakukan secara yuridis normatif dan pendekatan secara yuridis empiris. Pendekatan secara yuridis normatif yaitu pendekatan yang dilakukan dengan cara menelaah dan menelusuri teori-teori, konsep-konsep, serta peraturan-peraturan berkenaan dengan objek penelitian. Sedangkan dalam pendekatan yuridis empiris dilakukan dengan cara mengadakan penelitian lapangan, yaitu melihat fakta-fakta yang ada dalam praktek lapangan mengenai objek penelitian. Dengan pendekatan tipologi secara yuridis normatif dan yuridis empiris dimaksudkan untuk memperoleh gambaran yang jelas tentang sesuatu gejala keadaan objek yang diteliti. 


\section{Tipologi Pintu dan Jendela pada Fasad Rumah di Kampung Biru Arema Kelurahan Kiduldalem Muhammad Andi Finaldi Nurtantyo ${ }^{1}$, Respati Wikantiyoso ${ }^{2}$}

Langkah dalam penelitian ini meliputi pengumpulan data, analisa data kemudian membuat kesimpulan. Dalam penelitian yang tentunya bertujuan untuk memperoleh data dan informasi mengenai suatu kejadian atau keadaan saat ini pada objek. Dengan melihat keadaan yang telah dikaitkan dengan variabel-variabel yang ada.

Variabel dalam penelitian ini dapat diartikan sebagai segala sesuatu yang menjadi objek penelitian atau dapat pula diartikan sebagai faktor-faktor yang berperan dalam suatu peristiwa atau gejala yang diteliti. Variabel dalam penelitian merupakan ukuran sifat atau ciri yang dimiliki oleh angka-angka suatu kelompok atau suatu set yang berbeda dengan lainnya. Variabel dalam penelitian ini merupakan dari masing-masing tipe pintu dan jendela yang telah ditentukan melalui tahap metode pusposive sampling. Variabel dalam penelitian ini diukur melalui posisi letak pintu (fungsi), bentuk (ukuran) dan material (struktur).

Sampel penelitian sebanyak 32 kasus rumah tinggal yang menjadi objek studi dipilih melalui tahap metode purposive sampling (Tarore, Sangkertadi, \& Kaunang, 2016) yang memiliki kriteria didasarkan pada bentuk dasar elemen pintu yaitu pintu yang memiliki 1 daun pintu sebanyak 10 rumah dan yang memiliki 2 daun pintu sebanyak 22 rumah.

Kriteria pemilihan sampel didasarkan pada aspek letak rumah yang berada pada di jalan utama permukiman. Sirkulasi jalan utama menjadi dasar pemilihan sampel karena jalan tersebut dilalui oleh para pengunjung. Dengan dipilihnya sampel berdasarkan kriteria tersebut masyarakat luar permukiman (pengunjung) dapat mengetahui karakteristik Kampung biru arema selain warnanya.

\section{Pembahasan}

Berdasarkan pada survey lapangan, telah terdapat populasi studi kasus yang berada di wilayah permukiman RW 5 kampung biru arema. Sampel penelitian sebanyak 32 kasus rumah tinggal yang menjadi objek studi. Bangunan rumah tinggal tersebut dipilih menjadi objek melalui tahap metode purposive sampling yang memiliki kriteria didasarkan pada bentuk dasar elemen pintu yaitu pintu yang memiliki 1 daun pintu sebanyak 10 rumah dan yang memiliki 2 daun pintu sebanyak 22 rumah. Analisa pembahasan tipologi elemen pintu dan jendela pada fasad rumah menggunakan sampel dari 2 jenis pintu tersebut. Pemilihan objek bangunan ini diharapkan dapat mengidentifikasi elemen pintu dan jendela yang mendominasi karakteristik permukiman kampung biru. Setelah itu diidentifikasi masingmasing jenis pintu dengan variabel posisi letak pintu (fungsi), bentuk (ukuran) dan material.

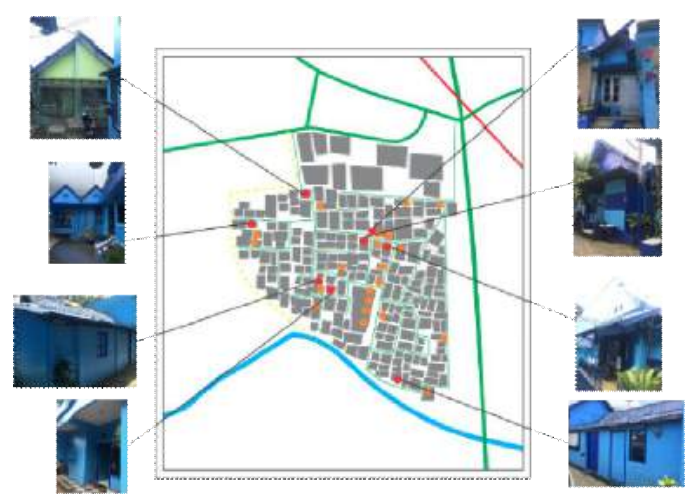

Gambar 2. Persebaran sampel rumah memiliki elemen 1 daun pintu (Sumber: Dokumentasi pribadi, 2018) 


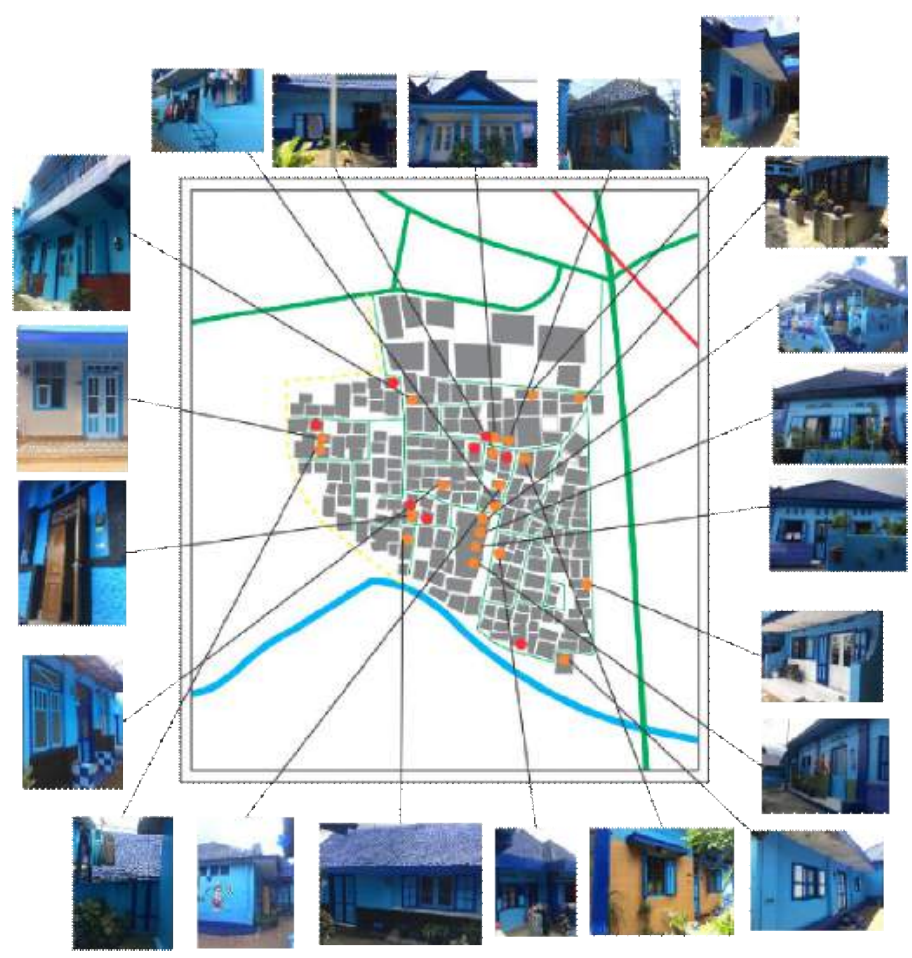

Gambar 3. Persebaran sampel rumah memiliki elemen 2 daun pintu (Sumber: Dokumentasi pribadi, 2018)

\section{Analisis Elemen Satu Daun Pintu dan Jendela pada Fasad Bangunan}

Berbagai macam posisi letak pintu yang memiliki maksud dan fungsi tertentu dalam suatu bangunan (Iswati, 2003). Posisi letak pintu pada umumnya terletak pada samping kanan atau samping kiri pada fasad bangunan dan juga terletak di tengah pada fasad bangunan. Seperti hal tersebut terdapat dua posisi letak pintu di kampung biru arema yaitu pada posisi samping kanan dan samping kiri dan posisi tengah pada fasad bangunan. Dari posisi letak pintu tersebut pasti memiliki maksud dan fungsi tertentu.

\section{Posisi elemen satu daun pintu yang terletak di tengah pada fasad bangunan}

Pada pintu yang berada di posisi tengah fasad bangunan dimaksudkan untuk adanya pembagian ruang pada zona depan yaitu ruang tamu dan ruang tidur. Selain itu juga dipengaruhi oleh lebar bangunan yang besar dari pemilik lahan. Dengan penempatan pintu berada di posisi tengah, terdapat juga penerapan jendela sebagai pendukung visual dan sirkulasi udara. Masing-masing jendela pada sisi yang mengapit pintu memiliki fungsi sebagai sirkulasi udara pada setiap ruang yang berada di zona depan. 


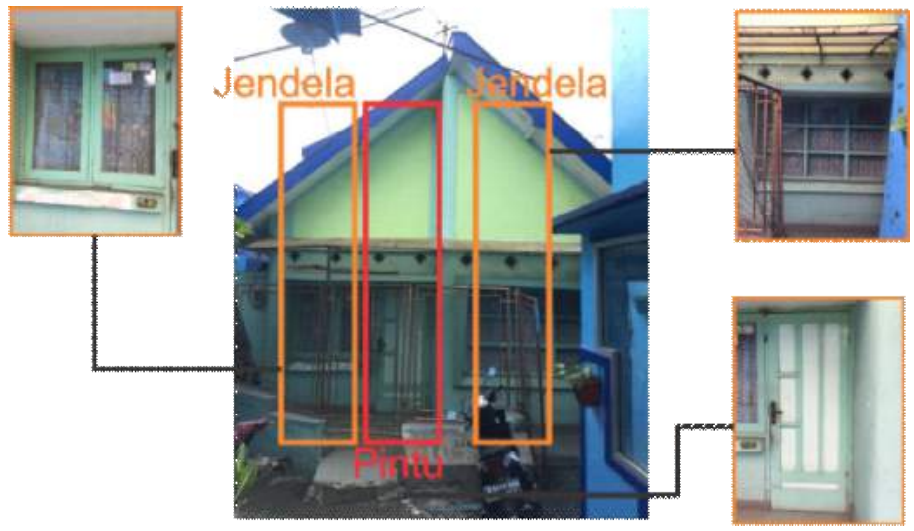

Gambar 4. Elemen satu daun pintu yang terletak di tengah pada fasad bangunan (Sumber: Dokumentasi pribadi, 2018)

Dalam bentukan satu daun pintu pada posisi tengah fasad bangunan merupakan jenis pintu utama yang memiliki bentukan geometris panil massif. Bentukan satu daun pintu hanya berupa satu lapis pintu dan hanya menggunakan material kayu jati. Sedangkan bentukan jendela sebagai pendukung adanya pintu identik bentukan geometris panil massif sama halnya dengan bentukan pintu. Bentukan jendela pelengkap visual pintu menerapkan jendela satu lapis penutup dari material kayu jati dan kaca bening dan dilapisi oleh tralis besi pada bangian dalam. Disamping itu juga diaplikasikan korden bermotif sebagai penutup untuk privasi penghuni. Pada setiap sisi jendela terdapat dak kanopi berbentuk massif yang menggunakan material cor beton. Untuk ventilasi lubang angin hanya teraplikasikan diatas jendela pada fasad bangunan.
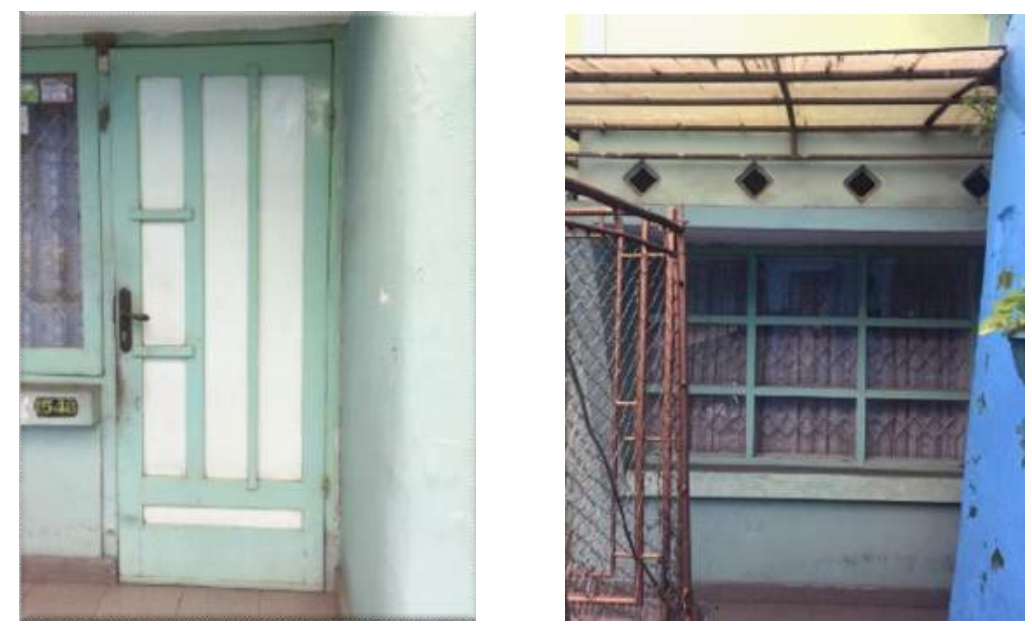

Gambar 5. Varian 1 elemen satu daun pintu yang terletak di tengah pada fasad bangunan (Sumber: Dokumentasi pribadi, 2018) 
Disamping itu juga terdapat variasi jenis pintu yang lain. Pintu tersebut merupakan pintu utama yang memiliki bentukan geometri sederhana yang merupakan berjenis pintu solid atau pintu panil. Bentukan daun pintu hanya terdapat satu lapis berukuran sekitar $90 \mathrm{~cm}$. Material yang digunakan yaitu kayu meranti yang dikombinasi dengan material kaca. Jenis pintu tersebut sangat umum pada masyarakat sekarang. Dengan faktor harga yang terjangkau dan fleksibilitas desain dan bentuk. Pintu panel tergolong fleksibel, karena desain pintu panel bisa divariasikan (dari sisi bentuk, desain, ukuran) dan panelnya pun dapat dirubah menjadi kaca. Hal ini juga selaras dengan bukaan jendela yang digunakan. Hanya terdapat pada bentukan jendela yang mendominasi elemen dinding pada sisi ruang dalam yang digunakan sebagai ruang tamu. Di sisi lain bentukan jendela lebih kecil dan sederhana, hal ini dikarenakan posisi jendela terdapat pada ruang yang membutuhkan privasi yang lebih.

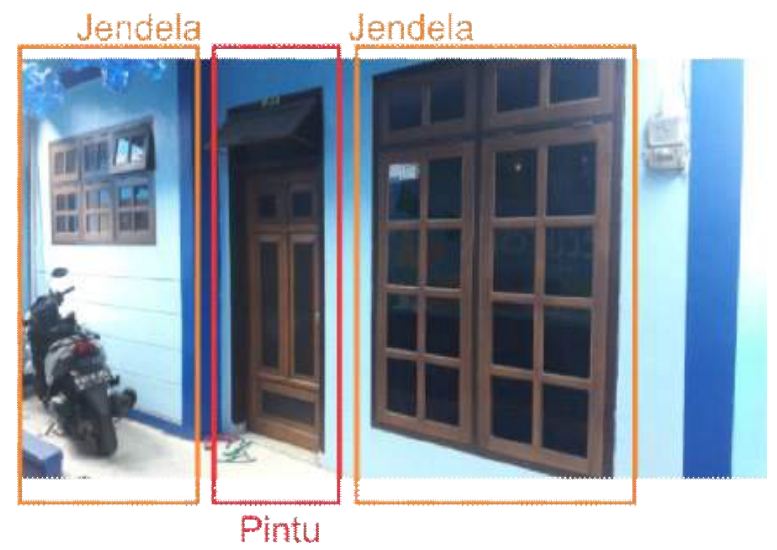

Gambar 6. Varian 2 elemen satu daun pintu yang terletak di tengah pada fasad bangunan (Sumber: Dokumentasi pribadi, 2018)

\section{Posisi elemen satu daun pintu yang terletak di samping pada fasad bangunan}

Pada pintu yang berada di posisi samping fasad bangunan dipengaruhi oleh minimnya lebar bangunan dari pemilik bangunan. Sehingga letak pintu yang berada di posisi samping hanya digunakan untuk ruang tamu. Letak pintu pada posisi samping tidak lepas dari keberadaan bukaan jendela sebagai pendukung visual dan sirkulasi udara.

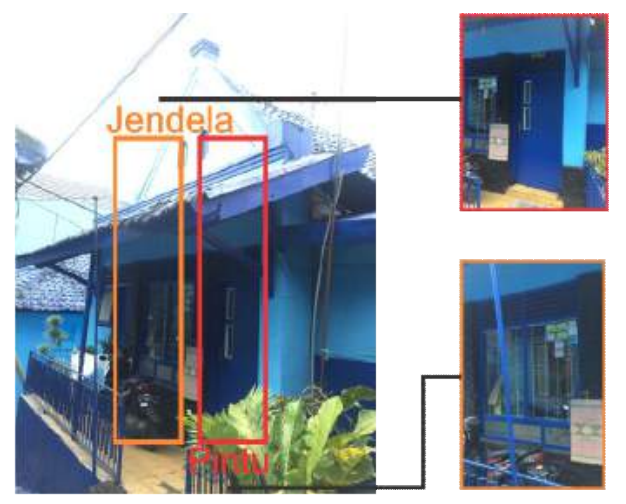

Gambar 7. Varian 1 elemen satu daun pintu yang terletak di samping fasad bangunan (Sumber: Dokumentasi pribadi, 2018) 


\section{Tipologi Pintu dan Jendela pada Fasad Rumah di Kampung Biru Arema Kelurahan Kiduldalem}

Muhammad Andi Finaldi Nurtantyo ${ }^{1}$, Respati Wikantiyoso ${ }^{2}$

Dalam bentukan satu daun pintu yang berada di posisi samping fasad bangunan identik dengan bentukan geometri sederhana. Pintu di posisi samping hanya berupa satu lapis dan hanya menggunakan material kayu jati. Sama halnya dengan jendela pada pintu di posisi tengah, bentukan jendela sebagai pendukung adanya pintu identik bentukan geometris panil massif. Bentukan jendela pelengkap visual pintu menerapkan jendela satu lapis penutup dari material kayu jati dan kaca bening dan dilapisi oleh tralis besi pada bangian dalam. Disamping itu juga diaplikasikan korden bermotif sebagai penutup untuk privasi penghuni. Untuk ventilasi lubang angin teraplikasikan diatas pintu dan jendela pada fasad bangunan.
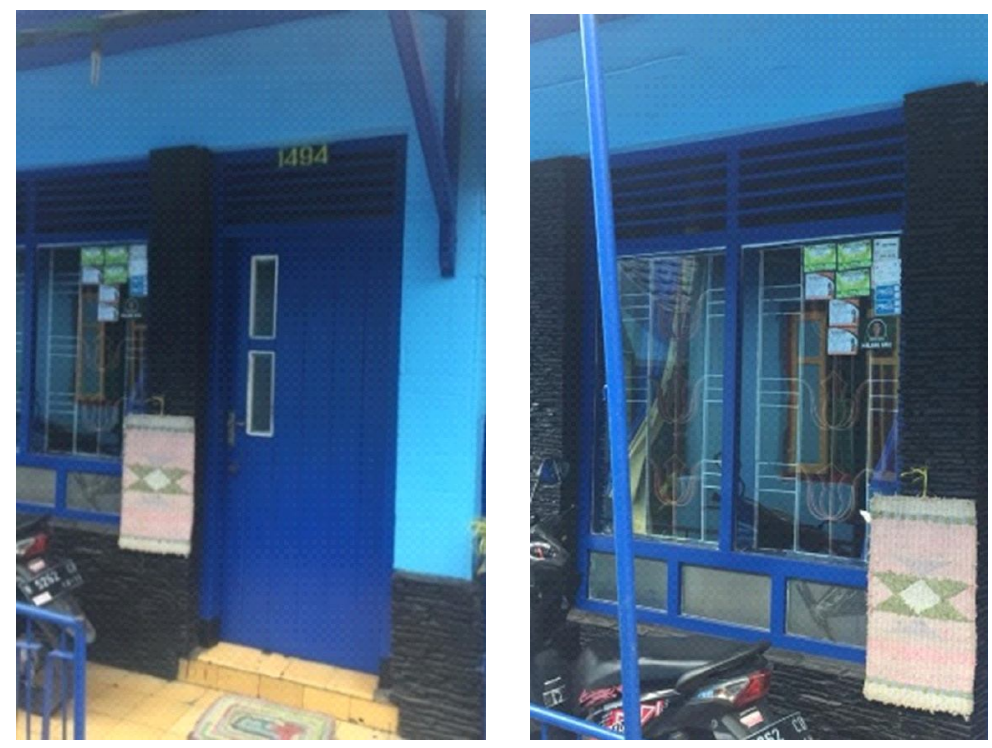

Gambar 8. Varian 1 elemen satu daun pintu yang terletak di samping fasad bangunan (Sumber: Dokumentasi pribadi, 2018)

Bentukan pintu dibawah ini memiliki bentuk polos sederhana dengan ukuran $80 \mathrm{~cm}$. Elemen pintu tersebut hanya terdiri dari satu lapis daun pintu yang hanya menggunakan material kayu olahan yaitu triplek atau multiplek. Bahan hasil olahan kayu memiliki harga lebih murah, jauh dibandingkan harga kayu solid. Daun pintu berbahan material kayu olahan seperti ini banyak digunakan bangunan rumah sederhana. Disisi lain terdapat bukaan jendela sederhana yang menggunakan material kayu dikombinasi dengan dominan material kaca gelap. Jenis jendela yang digunakan merupakan bentukan jendela kaca mati dan disampingnya terdapat penggunaan jendela krepyak. Bentukan jendela tersebut selaras dengan bentuk pintu yang sederhana. Penggunaan material dominan kaca gelap pada bukaan jendela berfungsi sebagai memasukkan cahaya kedalam ruangan dan penggunaan kaca krepyak selain difungsikan sebagai sirkulasi udara selain untuk memasukkan cahaya kedalam ruangan. Sirkulasi udara didukung juga dengan adanya penggunaan lubang ventilasi secara langsung. 


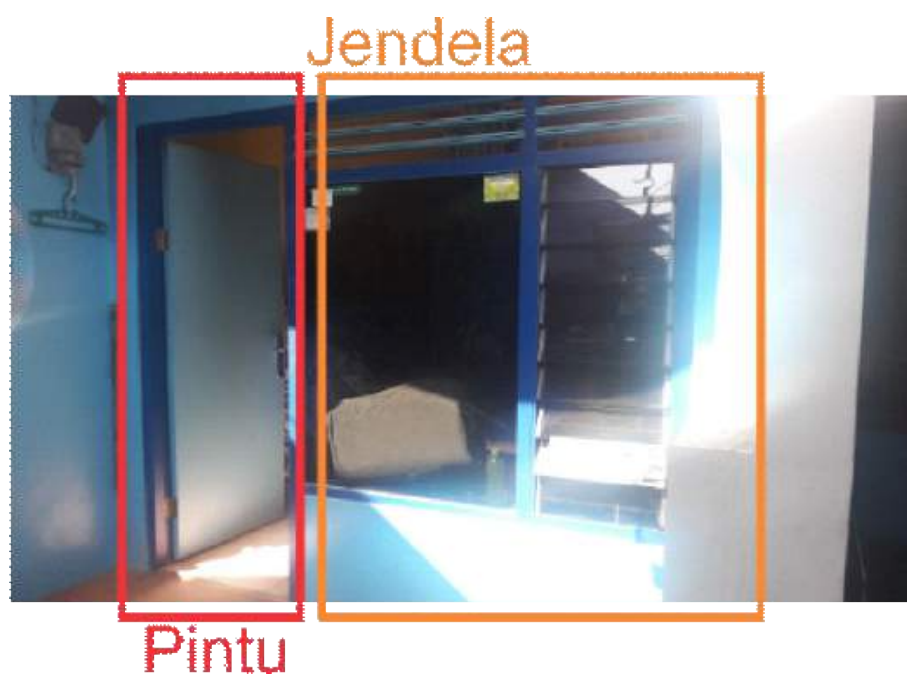

Gambar 9. Varian 2 elemen satu daun pintu yang terletak di samping fasad bangunan (Sumber: Dokumentasi pribadi, 2018)

\section{Analisis Elemen Dua Daun Pintu dan Jendela pada Fasad Bangunan}

Seperti halnya pada satu daun pintu, posisi pada dua daun pintu juga memiliki dua posisi letak pintu yaitu pada posisi samping kanan dan samping kiri dan posisi tengah pada fasad bangunan. Dari posisi letak pintu tersebut pasti memiliki maksud, pengaruh dan fungsi tertentu.

\section{Posisi elemen dua daun pintu yang terletak di tengah pada fasad bangunan}

Pada pintu yang berada di posisi tengah fasad bangunan dimaksudkan untuk adanya pembagian ruang pada zona depan yaitu ruang tamu dan ruang tidur. Selain itu juga dipengaruhi oleh lebar bangunan yang besar dari pemilik lahan. Dengan penempatan pintu berada di posisi tengah, terdapat juga penerapan jendela sebagai pendukung visual dan sirkulasi udara. Masing-masing jendela pada sisi yang mengapit pintu memiliki maksud sebagai sirkulasi udara pada setiap ruang yang berada di zona depan.

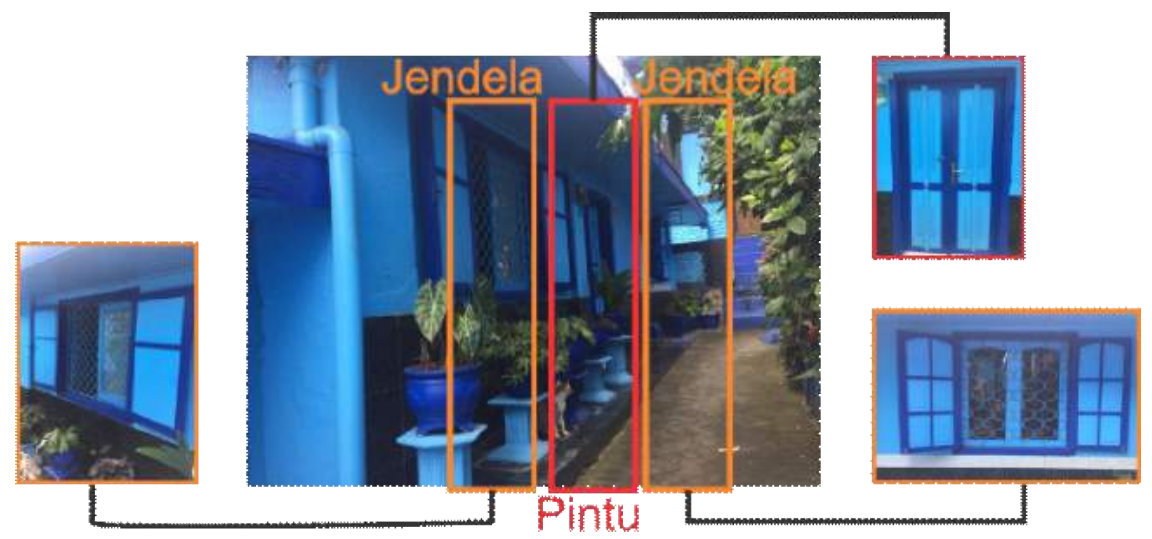

Gambar 10. Elemen dua daun pintu yang terletak di tengah fasad bangunan (Sumber: Dokumentasi pribadi, 2018) 


\section{Tipologi Pintu dan Jendela pada Fasad Rumah di Kampung Biru Arema Kelurahan Kiduldalem \\ Muhammad Andi Finaldi Nurtantyo ${ }^{1}$, Respati Wikantiyoso ${ }^{2}$}

Dalam bentukan dua daun pintu pada posisi tengah fasad bangunan merupakan jenis pintu utama yang memiliki bentukan geometris panil massif. Bentukan dua daun pintu berupa dua lapis pintu dan memiliki 4 buah daun pintu. Pada daun pintu lapis luar menggunakan material kayu jati dan memiliki ornamen panil massif yang simetris. Fungsi pintu bagian luar sebagai pelindung pertama karena berbahan kuat dan kokoh. Untuk lapis pintu dalam memiliki kecenderungan menggunakan material kayu jati dan dikombinasi dengan kaca bening. Fungsi pintu bagian dalam untuk memasukkan cahaya tambahan selain adanya jendela karena menggunakan kombinasi material kaca. Sedangkan bentukan jendela sebagai pendukung adanya pintu identik bentukan geometris panil massif sama halnya dengan bentukan pintu. Bentukan jendela pelengkap visual pintu menerapkan jendela dua lapis penutup dari material kayu jati pada bagian luar dan kombinasi kayu jati dengan kaca bening serta dilapisi oleh tralis besi diantara jendela bagian luar dan dalam. Fungsi pemakaian jendela dua lapis sama halnya dengan pengaplikasian pintu dua lapis. Disamping itu juga diaplikasikan korden bermotif sebagai penutup untuk privasi penghuni.
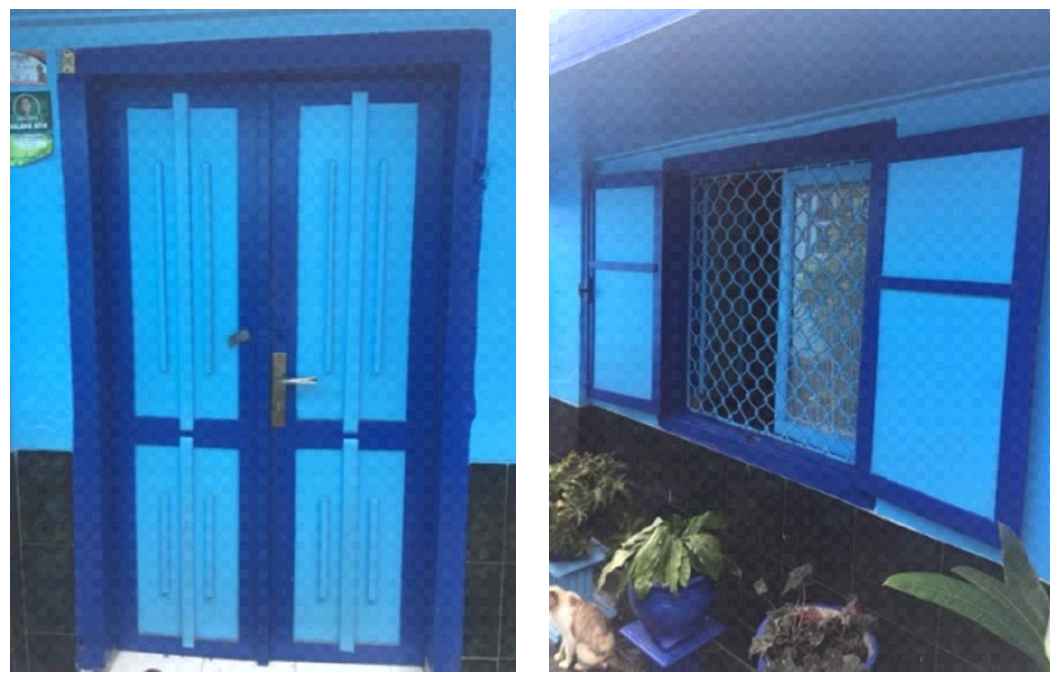

Gambar 11. Elemen dua daun pintu yang terletak di tengah fasad bangunan (Sumber: Dokumentasi pribadi, 2018)

\section{Posisi elemen dua daun pintu yang terletak di samping pada fasad bangunan}

Pada pintu yang berada di posisi samping fasad bangunan dipengaruhi oleh minimnya lebar bangunan dari pemilik bangunan. Sehingga letak pintu dan jendela yang berada di posisi samping hanya digunakan untuk ruang tamu. Letak pintu pada posisi samping tidak lepas dari keberadaan bukaan jendela sebagai pendukung visual dan sirkulasi udara. 


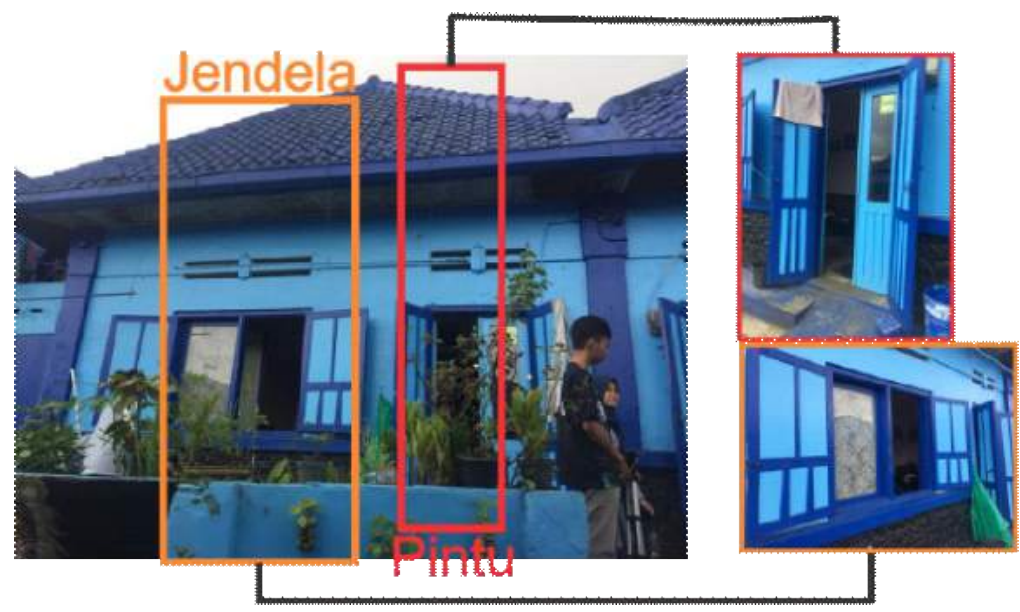

Gambar 12. Varian 1 elemen dua daun pintu yang terletak di samping fasad bangunan (Sumber: Dokumentasi pribadi, 2018)

Dalam bentukan dua daun pintu yang berada di posisi samping fasad bangunan identik dengan bentukan geometri panil massif. Pintu di posisi samping berupa dua lapis dan memiliki 4 buah daun pintu. Sama halnya dengan pintu yang berada di posisi tengah, pintu di posisi samping juga pada pintu bagian luar menggunakan material kayu jati. Fungsi pintu bagian luar digunakan sebagai perlindungan pertama karena mengguanakan material yang kuat dan kokoh. Untuk pintu bagian dalam cenderung menggunakan kombinasi material kayu jati dengan kaca bening. Fungsi pintu bagian dalam untuk memasukkan cahaya tambahan selain adanya jendela karena menggunakan kombinasi material kaca. Sedangkan bentukan jendela sebagai pendukung adanya pintu identik bentukan geometris panil massif sama halnya dengan bentukan pintu. Bentukan jendela pelengkap visual pintu menerapkan jendela dua lapis penutup dari material kayu jati pada bagian luar dan kombinasi kayu jati dengan kaca bening serta dilapisi oleh tralis besi diantara jendela bagian luar dan dalam. Fungsi pemakaian jendela dua lapis sama halnya dengan pengaplikasian pintu dua lapis. Disamping itu juga diaplikasikan korden bermotif sebagai penutup untuk privasi penghuni.
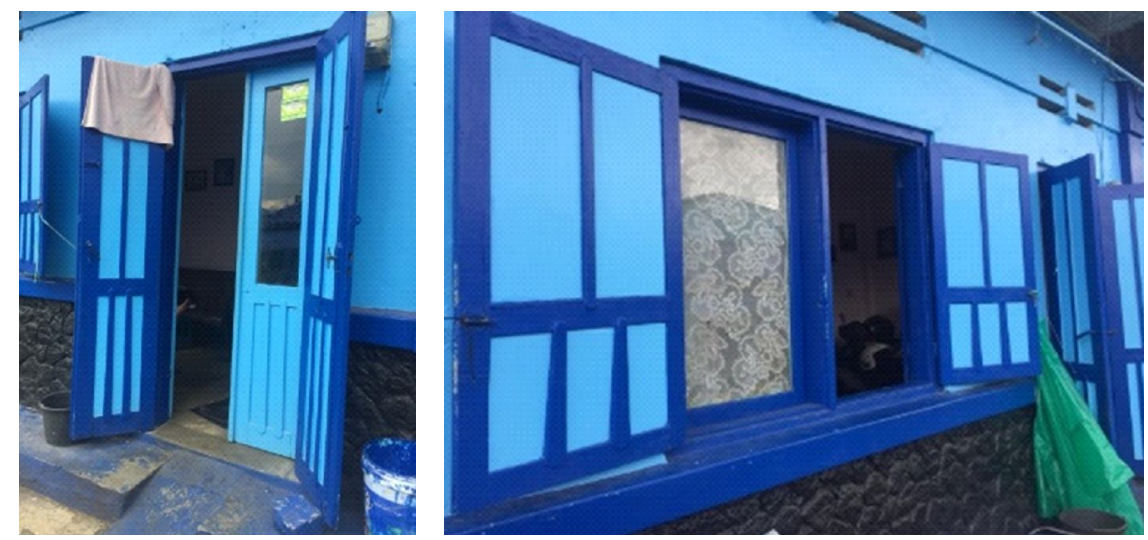

Gambar 13. Varian 1 elemen dua daun pintu yang terletak di samping fasad bangunan (Sumber: Dokumentasi pribadi, 2018) 


\section{Tipologi Pintu dan Jendela pada Fasad Rumah di Kampung Biru Arema Kelurahan Kiduldalem \\ Muhammad Andi Finaldi Nurtantyo ${ }^{1}$, Respati Wikantiyoso ${ }^{2}$}

Dibawah ini merupakan variasi lain dari jenis elemen bukaan yang memiliki 2 buah daun pintu. Elemen pintu tersebut merupakan pintu utama yang memiliki bentukan ukiran masif yang merupakan berjenis pintu solid atau pintu panel. Bentukan daun pintu hanya terdapat satu lapis berukuran sekitar 180cm lebarnya. Material yang digunakan yaitu kayu meranti yang diukir ukiran masif. Jenis pintu tersebut sangat umum pada masyarakat sekarang. Dengan faktor harga yang terjangkau dan fleksibilitas desain dan bentuk. Pintu panel tergolong fleksibel, karena desain pintu panel bisa. Hal ini berbeda dengan bukaan jendela yang digunakan. Bentukan jendela terlihat lebih sederhana dan lebih ramping. Material bukaan jendela menggunakan kayu meranti yang dikombinasi dengan kaca. Bukaan jendela yang digunakan merupakan jendela mati. Hal ini dapat menyebabkan hambatan sirkulasi udara pada jendela dan hanya dapat memasukkan cahaya. Di sisi lain terdapat juga bentukan jendela dengan posisi pada ruang yang membutuhkan privasi yang lebih.

\section{Analisis dan Konsep Kawasan Secara Keseluruhan}

- Pada elemen pintu denjordôk dan jendela yang $\mathrm{m}$ yang tidak memilil

- $\quad$ Terdapat juga 2 jen Bentukan tersebut

- Elemen pintu di po Tetapi terdapat $1 \mathrm{~b}$

- $\quad$ Terdapat 11 jenis $p$ kayu meranti pada

- $\quad$ Terdapat 9 jenis pi elemen yang di pos

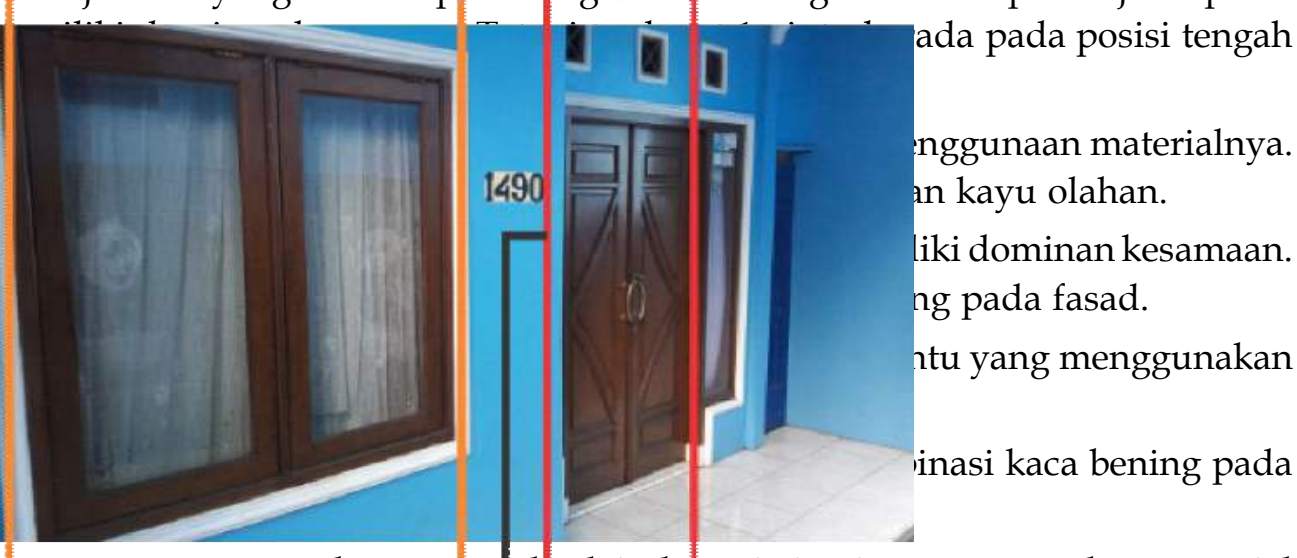

- Terdapat 1 jenis pilitu yang menggunakan ma er al celain kayu jati yaitu menggunakan material kayu meranti.

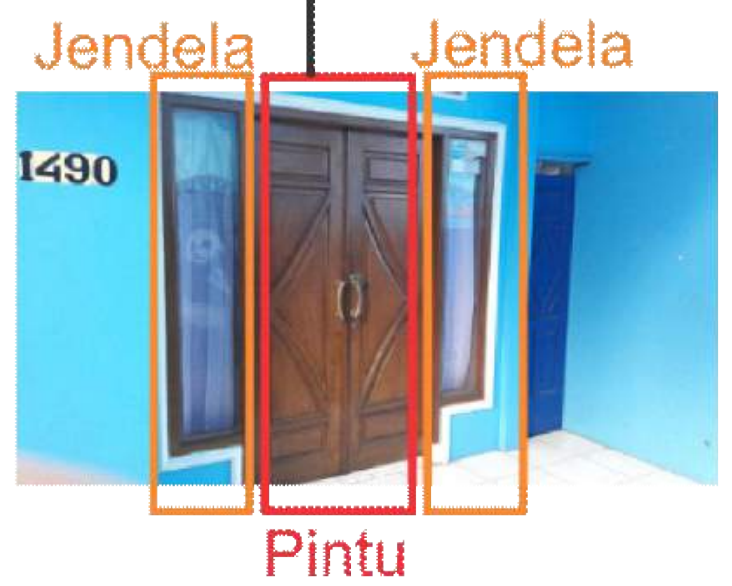

Gambar 14. Varian 2 elemen dua daun pintu yang terletak di samping fasad bangunan (Sumber: Dokumentasi pribadi, 2018) 


\section{Kesimpulan}

- Bentukan yang dominan yaitu geometris masif yang diterapkan pada rancangan desain pintu dan jendela di permukiman Kampung biru arema. bentukan tersusun secara vertikal dan horizontal yang simetris.

- Dominasi pintu dan jendela yang rangkap dapat menjadi karakteristik permukiman Kampung biru arema.

- Komposisi pintu dan jendela baik yang berada di tengah maupun di samping terhadap fasad rumah merupakan wujud bentukan simetris.

- Penggunaan material kayu jati dan kombinasi dengan kaca bening sebagai bahan utama yang dominan dalam rancangan desain pintu dan jendela di permukiman Kampung biru arema.

- Penggunaan jenis material pada bangunan rumah tinggal didasarkan pada status sosial dari pemilik rumah serta pengaruh dari dimensi lahan yang dimiliki.

- Desain rancangan dan penggunaan material merupakan penyesuaian terhadap waktu dan lingkungan sekitar.

\section{Referensi}

Hersanti, N. J., Pangarsa, G. W., \& Antariksa. (2008). TIPOLOGI RANCANGAN PINTU DAN JENDELA RUMAH TINGGAL KOLONIAL BELANDA DI KAYUTANGAN MALANG. arsitektur e-Journal, 157-171.

Iswati, T. Y. (2003). Tipologi-Tipologi Morfologi Ruang Dalam Rumah-Rumah di Kampung Kudusan Kota Gede. Jurnal Arsitektur Komposisi, I(2), 123-134.

Johnson, P. A. (1994). The Theory of Architecture: Concepts, Themes, \& Practice. New York: Van Nostrand Reinhold.

Keling, G. (2016). TIPOLOGI BANGUNAN KOLONIAL BELANDA DI SINGARAJA. Denpasar:, Volume 29, Nomor 2. Forum Arkeologi, 65-80.

Krier, R. (1988). Architectural Composition. London: Academy Editions.

Mariana, Y. (2013). TIPOLOGIBANGUNAN DIJALAN PAKUBOWONOKEBAYORAN BARU, JAKARTA SELATAN. ComTech, 33-42.

Marwati, S. A. (2017). TIPOLOGI BUKAAN PADA RUMAH TRADISIONAL BUGIS DI BENTENG SOMBA OPU MAKASSAR. National Academic Journal of Architecture, IV(2), 107-120. doi:https://doi.org/10.24252/ nature.v4i2a3

Mulyandari, H. (2012). TIPOLOGI RUMAH SUSUN YOGYAKARTA. TEKNIK SIPIL \& PERENCANAAN, XIV(2), 101-110.

Mulyandari, H. (2014). TIPOLOGI PERUBAHAN FUNGSI LAHAN BANGUNAN DI PERKOTAAN STUDI KASUS PERKEMBANGAN BANGUNAN KOMERSIAL PENGGAL JALAN MONJALI - JALAN ABU BAKAR ALI YOGYAKARTA. TEKNIK SIPIL \& PERENCANAAN, XVI(2), 15.

Rossi, A. (1982). The Architecture of The City. Cambridge: The MIT Press.

Tarore, L. T., Sangkertadi, \& Kaunang, I. R. (2016). KARAKTERISTIK TIPOLOGI ARSITEKTUR KOLONIAL BELANDA PADA RUMAH TINGGAL DI KAWASAN TIKALA. Jurnal Arsitektur DASENG UNSRAT Manado, 1-9. 
Tipologi Pintu dan Jendela pada Fasad Rumah di Kampung Biru Arema Kelurahan Kiduldalem Muhammad Andi Finaldi Nurtantyo ${ }^{1}$, Respati Wikantiyoso ${ }^{2}$

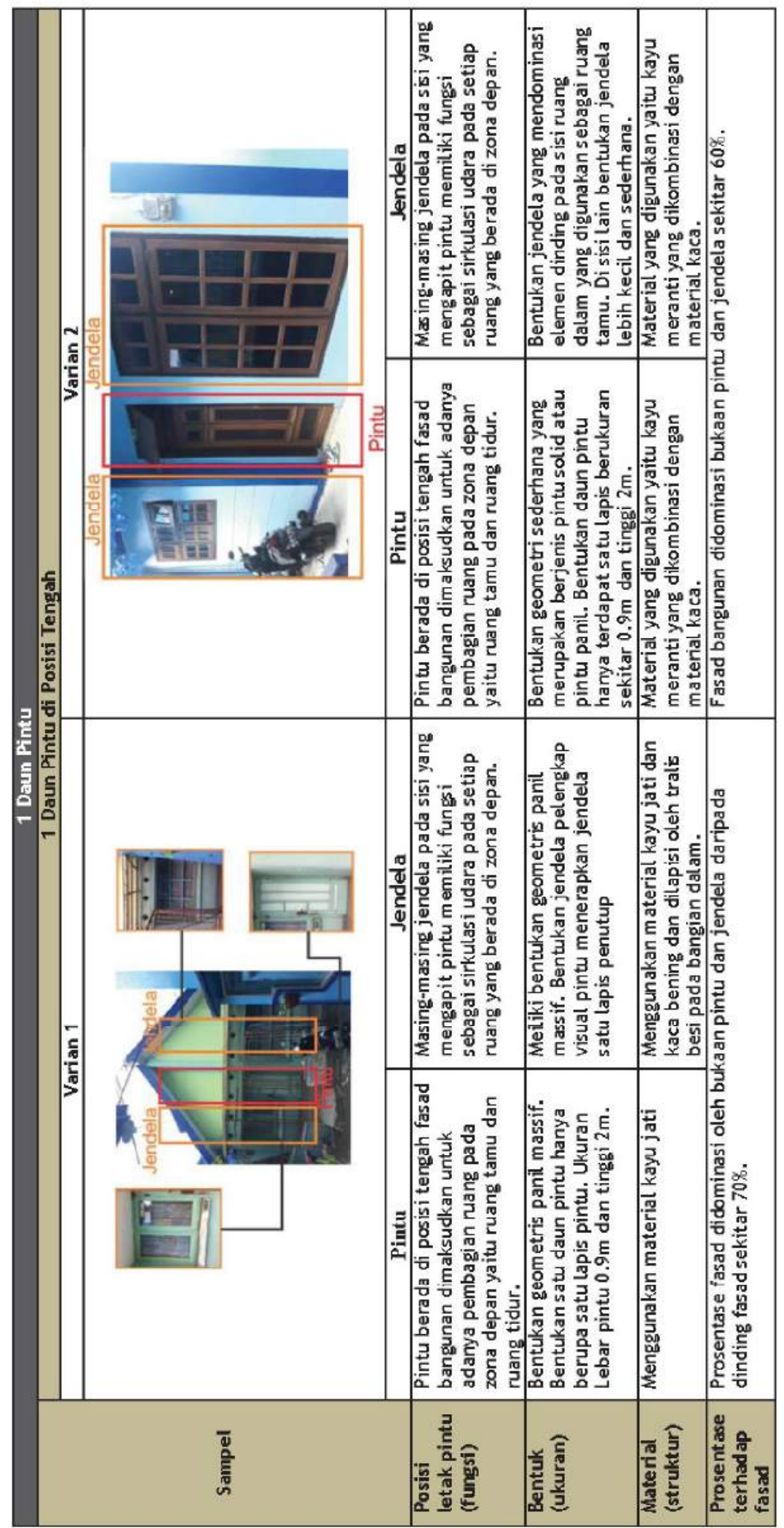


LOCAL WISDOM, Vol. 10 No. 2 Juli 2018

Local Wisdom Scientific Online Journal

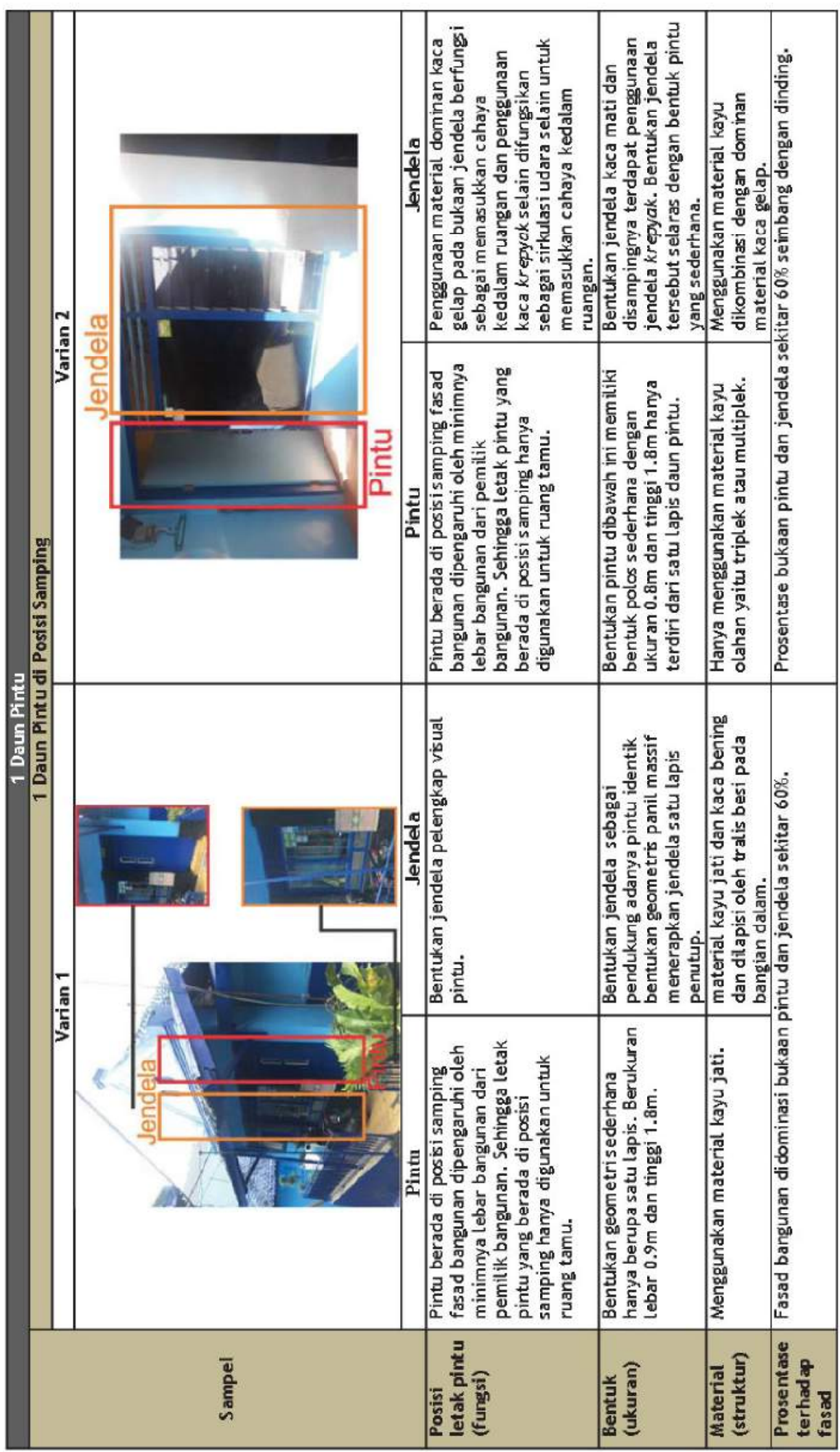


Tipologi Pintu dan Jendela pada Fasad Rumah di Kampung Biru Arema Kelurahan Kiduldalem Muhammad Andi Finaldi Nurtantyo ${ }^{1}$, Respati Wikantiyoso ${ }^{2}$

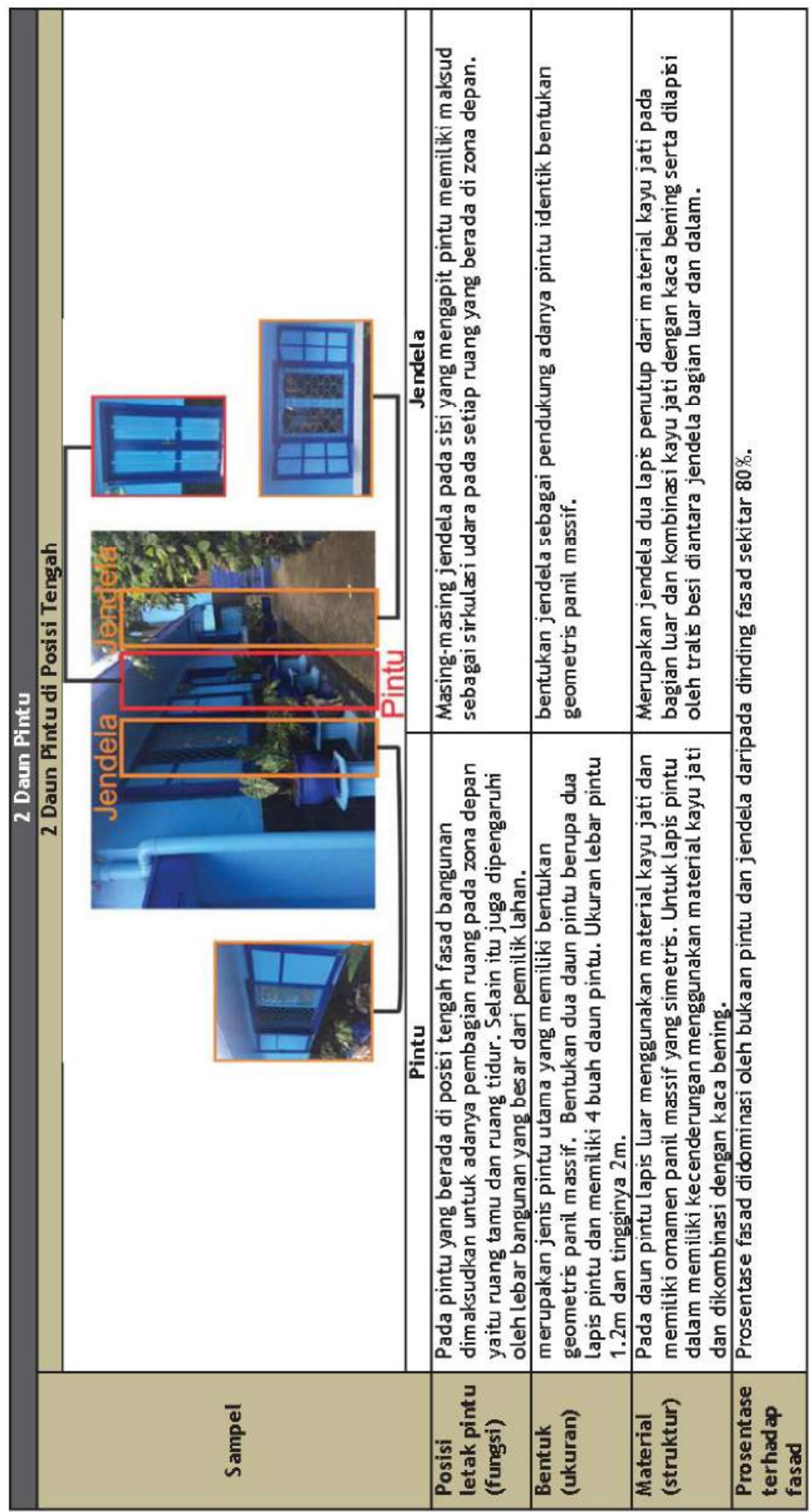


LOCAL WISDOM, Vol. 10 No. 2 Juli 2018

Local Wisdom Scientific Online Journal

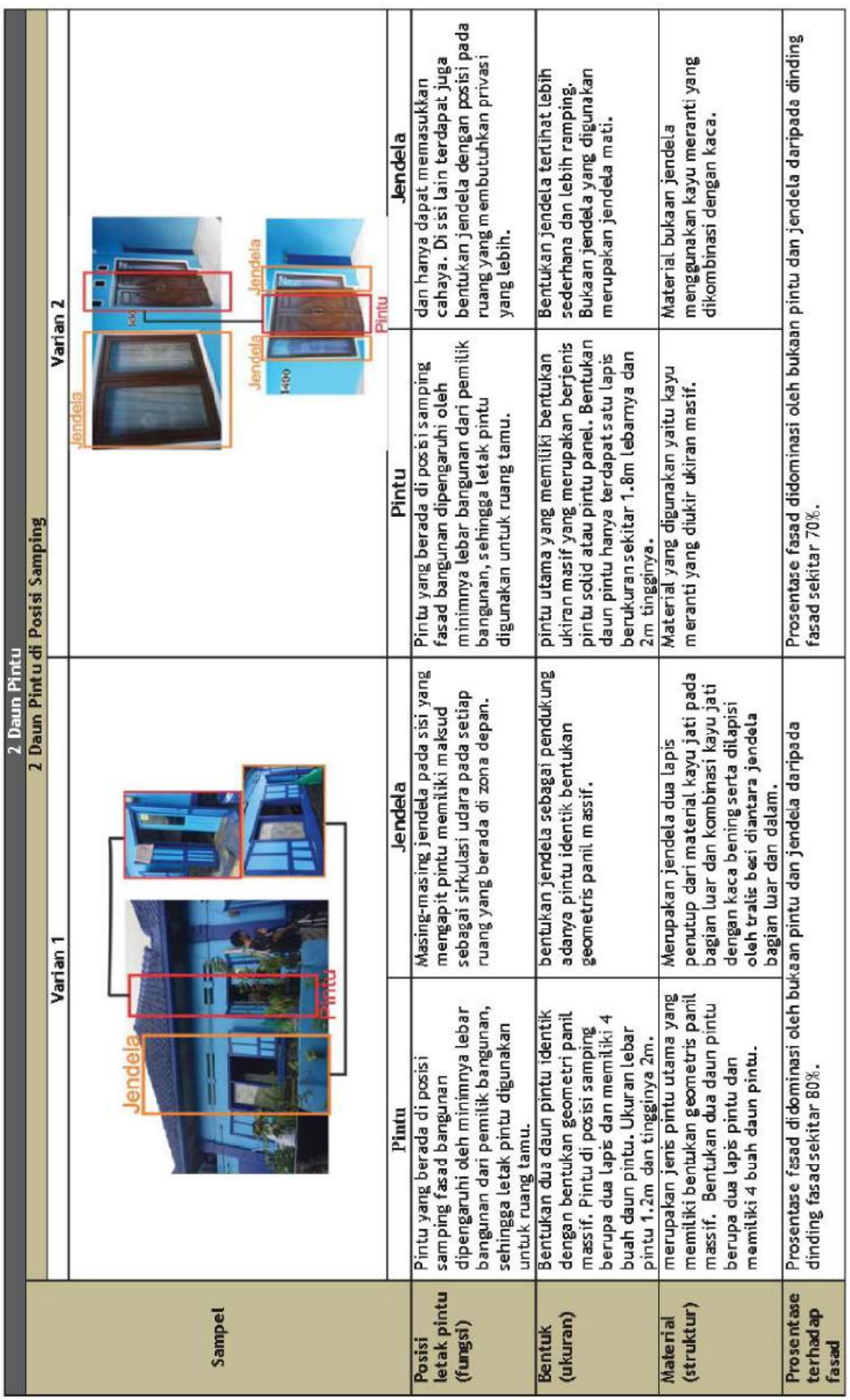


Tipologi Pintu dan Jendela pada Fasad Rumah di Kampung Biru Arema Kelurahan Kiduldalem Muhammad Andi Finaldi Nurtantyo ${ }^{1}$, Respati Wikantiyoso ${ }^{2}$

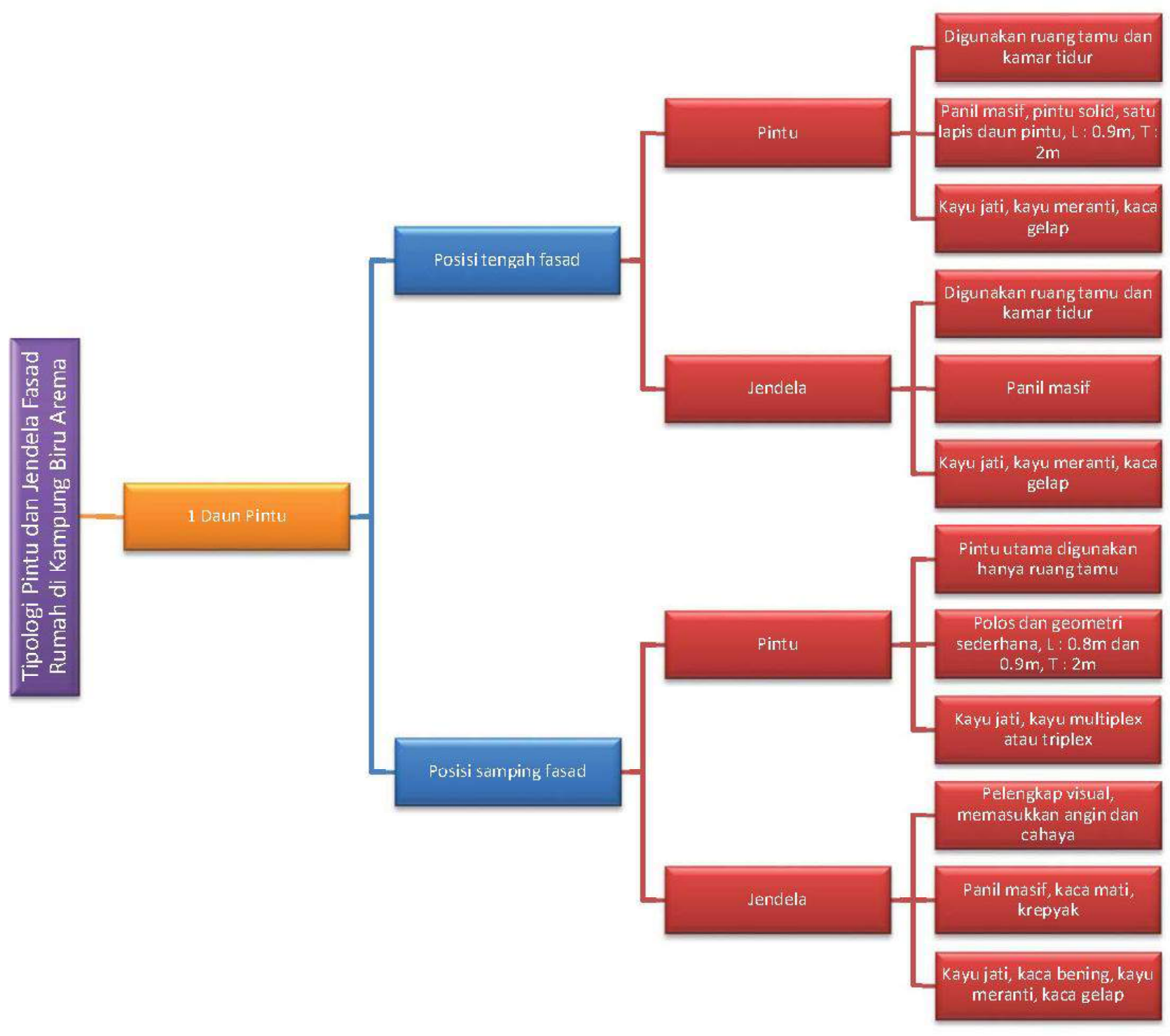


LOCAL WISDOM, Vol. 10 No. 2 Juli 2018

Local Wisdom Scientific Online Journal

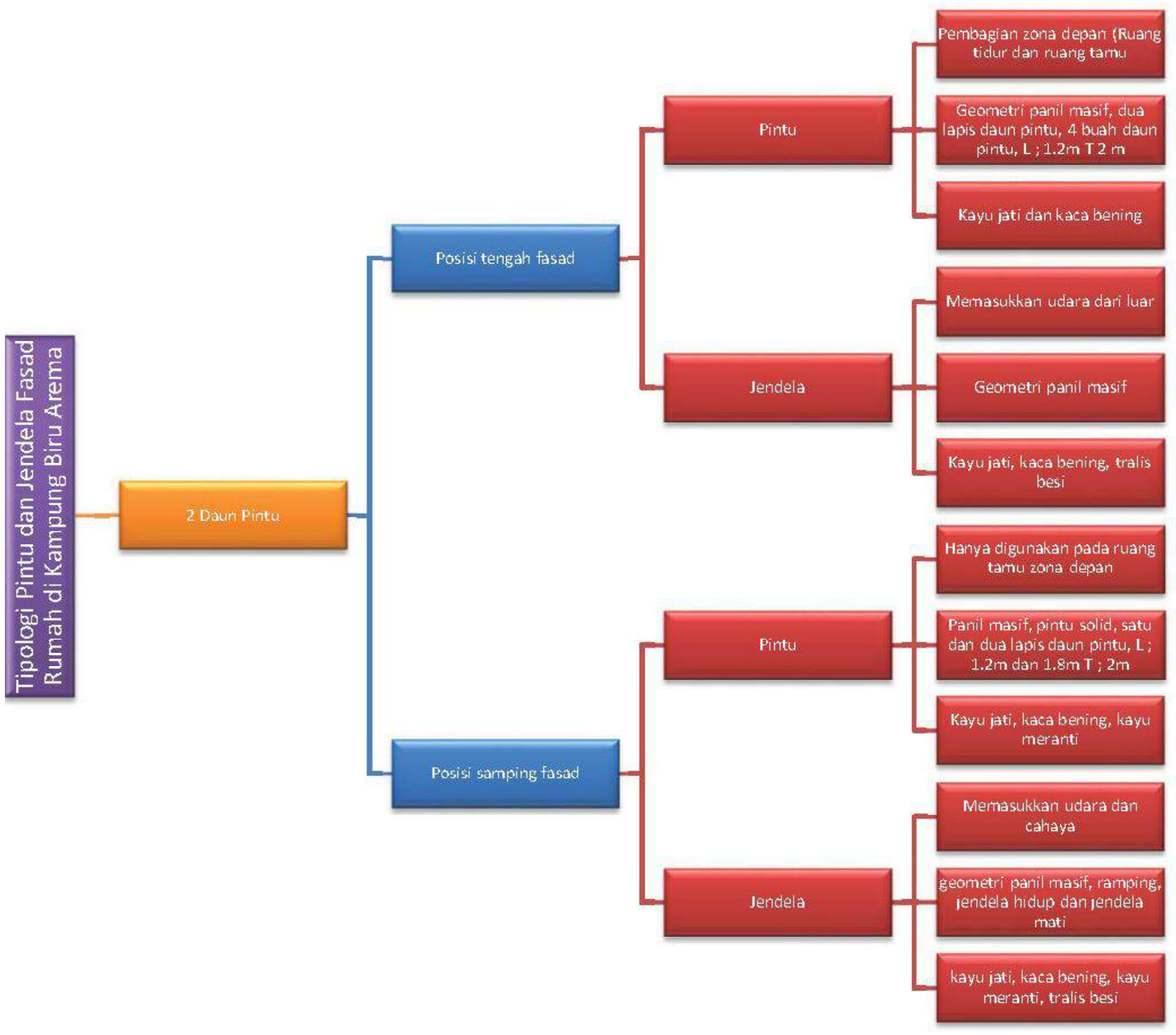

